Finanse, Rynki Finansowe, Ubezpieczenia nr 3/2017 (87), cz. 1

\title{
Kwalifikacje audytorów wewnętrznych na świecie
}

\author{
Kazimiera Winiarska"
}

\begin{abstract}
Streszczenie: $\mathrm{Cel}$ - Celem artykułu jest zaprezentowanie badań oceniających stan wykształcenia, kompetencji i umiejętności audytorów wewnętrznych na świecie.

Metodologia badania - W przygotowaniu artykułu wykorzystano raporty opracowane na zlecenie Instytutu Audytorów Wewnętrznych (IIA).

Wynik - Popularyzacja wyników ankiety IIA uświadamia rolę audytu wewnętrznego na świecie.

Oryginalność/wartość - Pytania zawarte w ankietach IIA mogą być wykorzystane do badań naukowych w poszczególnych krajach, w których audyt wewnętrzny jest uregulowany prawnie.
\end{abstract}

Słowa kluczowe: audytor wewnętrzny, kwalifikacje audytorów wewnętrznych

\section{Wprowadzenie}

Instytut Audytorów Wewnętrznych (IIA), celem zinwentaryzowania stanu audytu wewnętrznego na świecie, przeprowadził w 2006 i 2010 roku badania ankietowe w różnych regionach świata i sektorach gospodarki. Wyniki badania zaprezentowane w czterech raportach wnoszą dużo interesujących spostrzeżeń (Winiarska, 2017, s. 59-71).

\section{Raporty IIA w sprawie stanu i wykształcenia audytorów wewnętrznych}

W raportach wykonanych na zlecenie IIA zaprezentowano:

- wiek audytorów wewnętrznych (rys. 1),

- płeć audytorów wewnętrznych według regionów (rys. 2 ),

- poziom wykształcenia audytorów wewnętrznych (rys. 3),

- wykształcenie audytorów wewnętrznych według specjalności (rys. 4),

- profesjonalne certyfikaty audytorów wewnętrznych (tab. 1),

- metody oceny audytorów wewnętrznych (rys. 5)

- kompetencje ogólne audytorów wewnętrznych (rys. 6),

- umiejętności behawioralne audytorów wewnętrznych (rys. 7),

- umiejętności techniczne audytorów wewnętrznych (rys. 8),

* prof. zw. dr hab. Kazimiera Winiarska, Uniwersytet Szczeciński, WNEiZ, Instytut Rachunkowości, e-mail: kr234@wneiz.pl. 
- wiedzę audytorów wewnętrznych (rys. 9),

- narzędzia i techniki audytu wewnętrznego (rys. 10),

- typy wykonywanych zadań audytorskich (rys. 11).

Ankietowani audytorzy wewnętrzni charakteryzują się dużym doświadczeniem zawodowym. Najwięcej audytorów miało od 35 lat do 44 lat oraz od 45 do 54 lat. Można zaobserwować w 2010 roku wzrost liczby audytorów w wieku 26-34 lata. Znikoma była natomiast liczba audytorów mających mniej niż 25 lat lub więcej niż 65 lat (rys. 1).

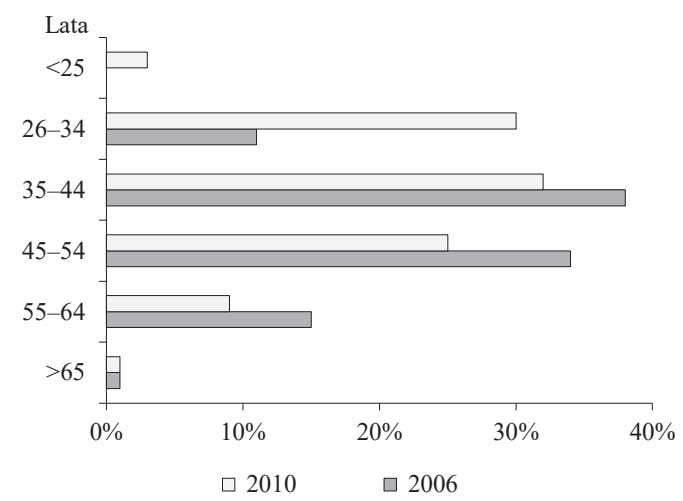

Rysunek 1. Wiek audytorów wewnętrznych

Źródło: Alkafaji, Hussain, Khallaf, Meldalawieh (2010), s. 6.

Oceniając płeć audytorów wewnętrznych, zauważa się dwukrotną przewagę mężczyzn, a na Środkowym Wschodzie nawet trzykrotną, co wynika z tradycji tego regionu. Niewielkie różnice w liczbie mężczyzn i kobiet obserwuje się w USA i Kanadzie, co świadczy

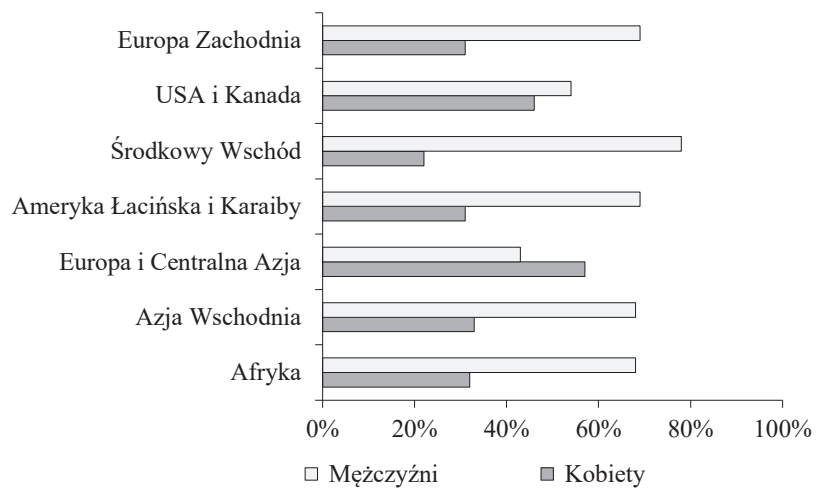

Rysunek 2. Płeć audytorów wewnętrznych według regionów

Źródło: Alkafaji, Hussain, Khallaf, Meldalawieh (2010), s. 6. 
o równouprawnieniu w wykonywaniu zawodu. W Europie i Azji Centralnej audytorami wewnętrznymi są w większości kobiety, co ma związek z feminizacją zawodu w zakresie rachunkowości (rys. 2).

Większość audytorów wewnętrznych była ekonomistami z tytułem magistra lub licencjata. Mniej było magistrów i licencjatów z wykształceniem nieekonomicznym. Niewielu było absolwentów szkół średnich oraz naukowców z tytułem doktora lub wyższym (rys. 3).

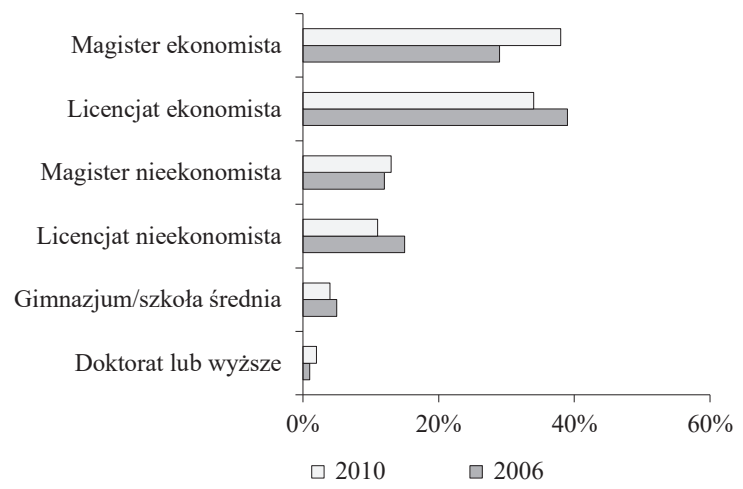

Rysunek 3. Poziom wykształcenia audytorów wewnętrznych

Źródło: Alkafaji, Hussain, Khallaf, Meldalawieh (2010), s. 6.

Analizując wykształcenie audytorów wewnętrznych według specjalności, zauważa się przeważający udział osób, które studiowały rachunkowość (ok. 50\%). W następnej kolejności była to ekonomia, biznes i finanse (20-25\%). Specjalistów z audytu wewnętrznego i zewnętrznego było niewielu ponad 10\% audytorów - rysunek 4 .

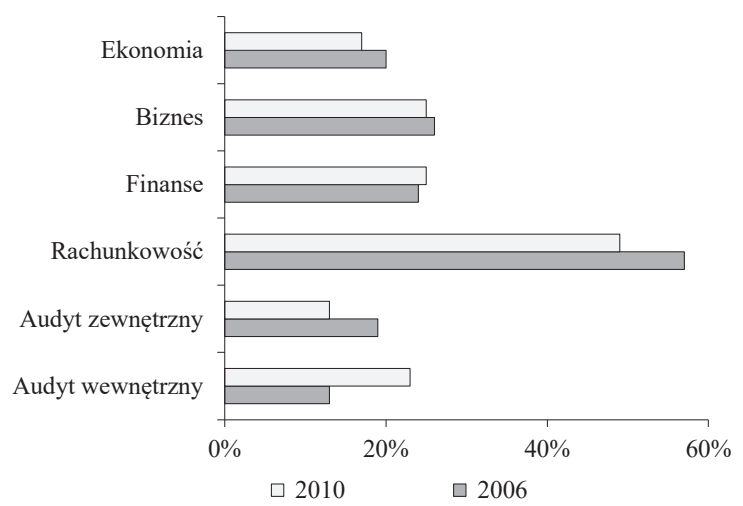

Rysunek 4. Wykształcenie audytorów wewnętrznych według specjalności

Źródło: Alkafaji, Hussain, Khallaf, Meldalawieh (2010), s. 7. 
W tabeli 1 zaprezentowano certyfikaty audytorów wewnętrznych. W grupie ankietowanych audytorów wewnętrznych najwięcej z nich miało certyfikaty CIA - 30,3\% oraz CA/ CPA/ACCA/ACA - 20,4\%. Część audytorów wewnętrznych (w granicach 4-10\%) dysponowało certyfikatami CISA/QiCA, CFE, MIIA/PIIA, CMA/CIMA/CGA. Od 2\% do 4\% audytorów wewnętrznych miało certyfikaty CCSA, IT/ICT, FCA/FCCA/FCMA, CAT/AAT, CGAP, CFSA. Nieliczna grupa audytorów wewnętrznych deklarowała posiadanie certyfikatów CRM, CIPFA/CGFM, CIDA/CBA, CFA. Najbardziej pożądane są certyfikaty CIA oraz certyfikaty z zakresu rachunkowości. W następnej kolejności są to certyfikaty systemów informatycznych i nadużyć (fałszerstw).

\section{Tabela 1}

Profesjonalne certyfikaty audytorów wewnętrznych

\begin{tabular}{lc}
\hline Certyfikaty profesjonalne & Procent \\
\hline Certyfikowany audytor wewnętrzny (CIA) & 30,3 \\
Certyfikat rachunkowości (CA/CPA/ACCA/ACA) & 20,4 \\
Audytowanie systemów informatycznych (CISA/QiCA) & 9,7 \\
Badanie nadużyć (CFE) & 5,3 \\
Inne czynności audytu wewnętrznego (MIIA/PIIA) & 4,2 \\
Zarządzanie/rachunkowość (CMA/CIMA/CGA) & 4,0 \\
Certyfikacja w kontrolnej samoocenie (CCSA) & 3,7 \\
Systemy informatyczne (IT/ICT) & 2,4 \\
Zaawansowany statut profesjonalny ((FCA/FCCA/FCMA) & 2,4 \\
Rachunkowość - poziom techniczny (CAT/AAT) & 2,1 \\
Certyfikowany profesjonalista audytu (CGAP) & 2,0 \\
Certyfikowany audytor usług finansowych (CFSA) & 2,0 \\
Zarzadzanie innym ryzykiem/samoocena kontroli (CRM) & 1,3 \\
Auditing nadzoru/finanse (CIPFA/CGFM) & 1,2 \\
Inny wyspecjalizowany audyt finansowy (CIDA/CBA) & 0,8 \\
Certyfikowany audytor finansowy (CFA) & 0,7 \\
\hline
\end{tabular}

Źródło: Alkafaji, Hussain, Khallaf, Meldalawieh (2010), s. 9-10.

Audytorzy wewnętrzni są oceniani głównie przez kierowników jednostek (75\%). W 3545\% audytorzy są oceniani przez klientów, bezpośrednich przełożonych, kierowników niższego stopnia działu audytu lub przez samoocenę. Około $20 \%$ ocen wynika z opinii współpracowników działu audytu lub pracowników innych działów (rys. 5). 


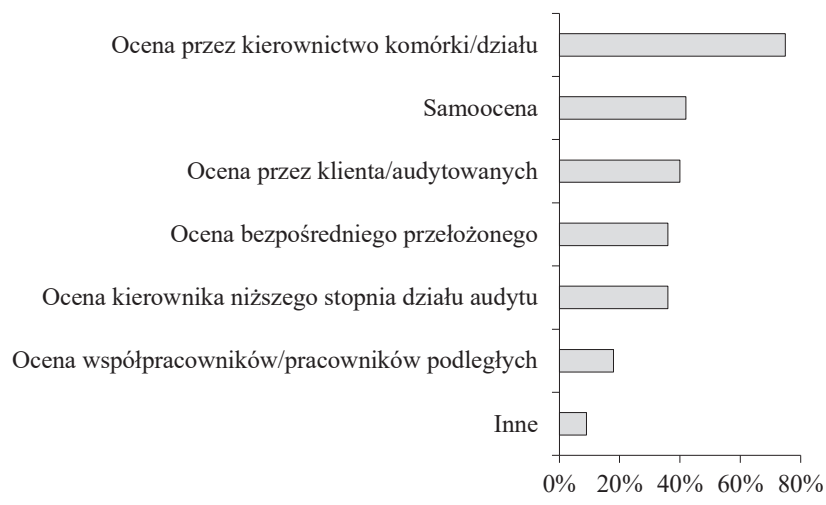

Rysunek 5. Metody oceny audytorów wewnętrznych

Źródło: Alkafaji, Hussain, Khallaf, Meldalawieh (2010), s. 8.

\section{Raporty IIA w sprawie kompetencji i umiejętności audytorów wewnętrznych}

Jak wynika z rysunku 6, w ocenie kompetencji ogólnych audytorów wewnętrznych najbardziej cenne są komunikatywność oraz umiejętności identyfikacji i rozwiązywania problemów (ponad $80 \%$ ). Prawie 70\% audytowanych wskazało na zdolność promowania wartości audytu wewnętrznego, znajomość zmian w sektorze, regulacjach i standardach oraz umiejętności organizacyjne. Najmniejsze znaczenie miały kompetencje w zakresie znajomości kultury i języka obcego kraju oraz technik i narzędzi informatycznych.

Oceniając umiejętności behawioralne audytorów wewnętrznych, najwyżej wyceniono umiejętność zachowania tajemnicy, obiektywność i komunikatywność (80-90\%). W następnej kolejności były to: obiektywny osąd, umiejętność współpracy z kierownictwem, wrażliwość na nadzór i etykę (70-80\%). Pracę zespołową, relacje międzyludzkie, samodzielność w pracy, budowanie zespołu, przywództwo i wpływ wskazało $50-60 \%$ ankietowanych. Umiejętność mediacji, zarządzania ludźmi i zmianami uzyskała $40-50 \%$ wskazań. Umiejętności behawioralne audytorów wewnętrznych zaprezentowano na rysunku 7.

Wśród umiejętności technicznych audytora wewnętrznego najwyższe noty otrzymały: rozumienie biznesu, analiza ryzyka, identyfikacja typów kontroli (ok. 70\%). W granicach 50-60\% wskazano znajomość narzędzi i technik nadzoru, ryzyka i kontroli, analizy procesów biznesowych, narzędzi i technik zbierania i analizy danych, badań operacyjnych i kierowniczych oraz narzędzi i technik rozwiązywania problemów. 


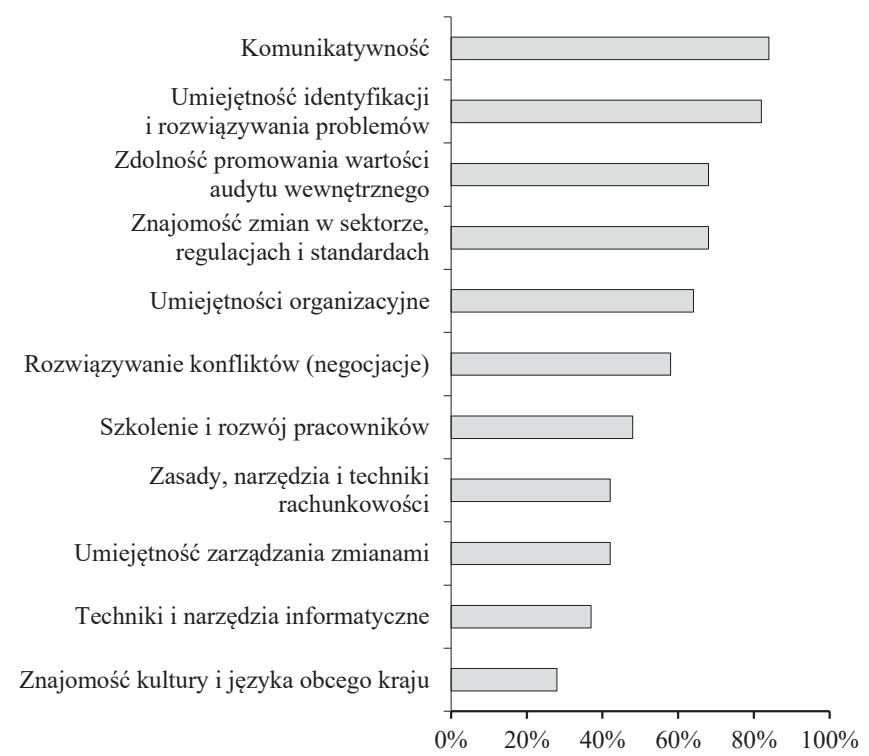

Rysunek 6. Kompetencje ogólne audytorów wewnętrznych

Źródło: Bailey (2010), s. 5.

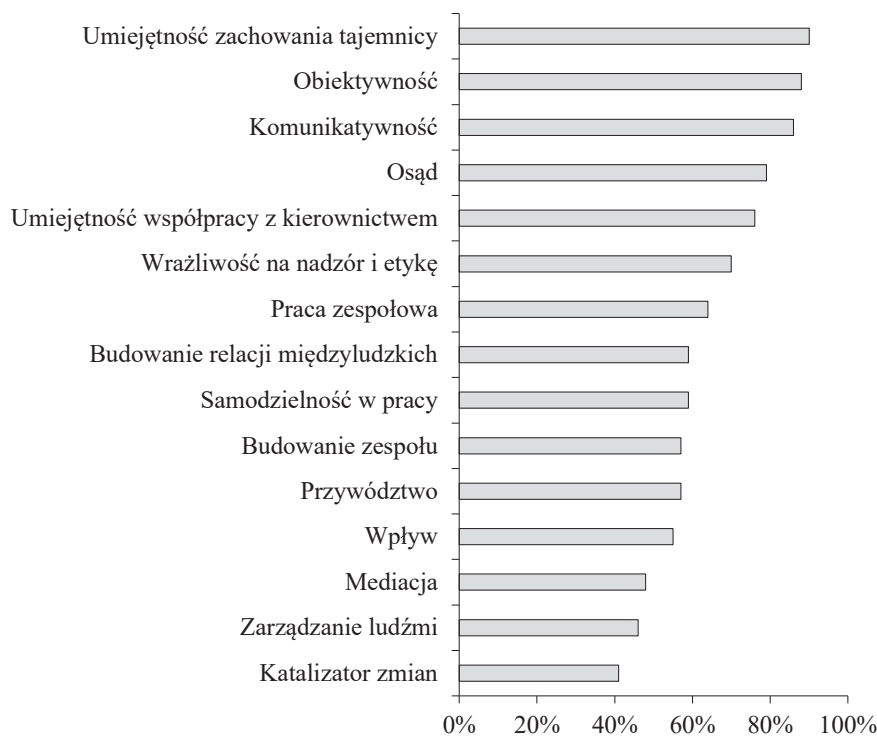

Rysunek 7. Umiejętności behawioralne audytorów wewnętrznych

Źródło: Bailey (2010), s. 11. 
Niżej oceniono negocjacje, zarządzanie projektami, techniki kryminalistyczne (4045\%). Umiejętności korzystania z komputerów, analizy finansowej, próbkowania statystycznego wskazano w granicach $30-40 \%$ przypadków. Najniżej ocenione są prognozowanie, zarządzanie jakością, znajomość ISO i zbilansowanej karty dokonań (ok. 20\%). Umiejętności techniczne audytorów wewnętrznych zaprezentowano na rysunku 8.

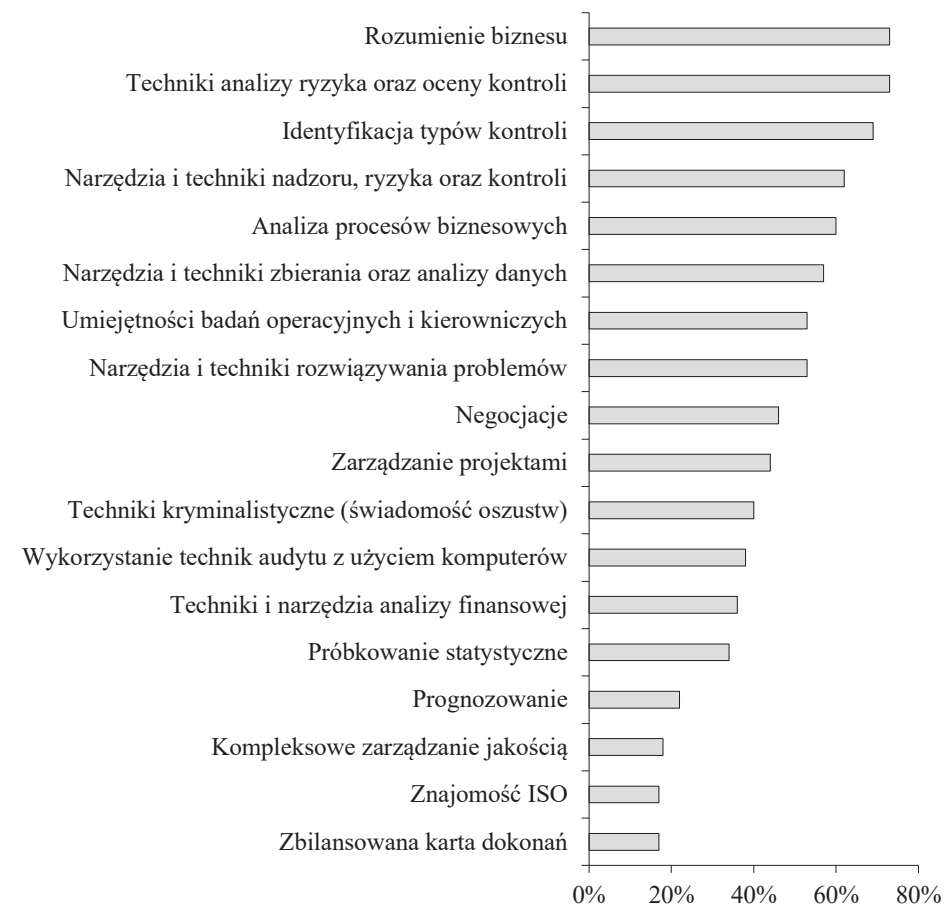

Rysunek 8. Umiejętności techniczne audytorów wewnętrznych

Źródło: Bailey (2010), s. 17.

Wiedza audytora wewnętrznego powinna obejmować głównie audyt i standardy audytu wewnętrznego (80\%). W następnej kolejności ma to być wiedza z zakresu etyki, oszustw, zarządzania ryzykiem, zmian w standardach, wiedzy specjalistycznej o sektorze i technik nadzoru (50-60\%). Ponad 40\% wskazań dotyczyło wiedzy z zakresu rachunkowości finansowej, zarządzania biznesem oraz kultury organizacji. Poniżej $40 \%$ oceniono wiedzę z zakresu prawa gospodarczego, finansów, informatyki i rachunkowości zarządczej. Najmniej warta jest wiedza z zakresu oceny jakości, ekonomii i marketingu (10-20\%). Zakresy wiedzy pożądanej od audytorów wewnętrznych zaprezentowano na rysunku 9. 


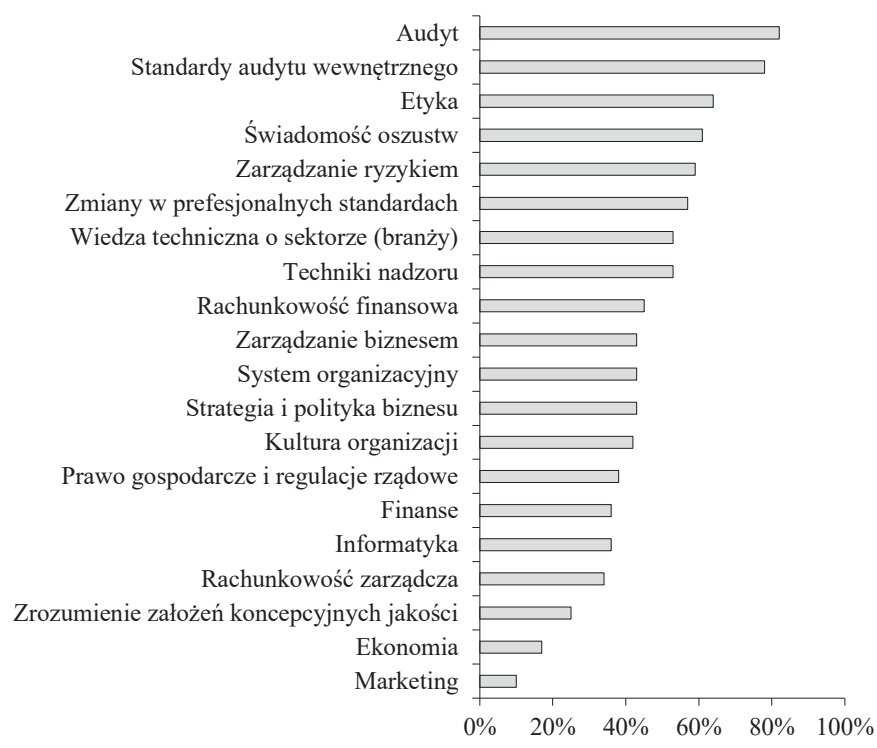

Rysunek 9. Wiedza audytorów wewnętrznych

Źródło: Bailey (2010), s. 23.

Oceniając narzędzia i techniki audytu wewnętrznego (rys. 10), najwyższe notowania uzyskało zarządzanie ryzykiem, komunikacja elektroniczna i przegląd analityczny (60$70 \%$ ). W blisko $50 \%$ przypadków wskazano użyteczność próbkowania statystycznego, elektronicznego dokumentowania i zbierania danych oraz audyt wspierany komputerowo. Samoocena kontroli, diagramy sekwencji działań i benchmarketing oceniono na około $40 \%$. Najniżej oceniono audyt ciągły, aplikacje mapujące procesy, narzędzia oceny jakości, zbilansowaną kartę dokonań, techniki kompleksowego zarządzania i oprogramowania do mapowania procesów (20-30\%).

W rankingu typów wykonywanych czynności audytorskich zauważa się, że najczęściej jest to audyt operacyjny, audyt zgodności z aktami wykonawczymi, ocena efektywności systemów kontroli, audyt ryzyka finansowego oraz badanie oszustw i nieprawidłowości (80-100\%). W granicach $60-80 \%$ są to audyty systemów informatycznych, ryzyka informacji, zarządzania ryzykiem, zarządzania procesami, ładu korporacyjnego i oceny zabezpieczeń. W około $60 \%$ jest to wsparcie audytu zewnętrznego, audyt kierownictwa i wsparcie po katastrofach. Zapewnienie szkoleń pracowników, audytu etyki, outsourcingu, przeglądu, powiązań między strategią i dokonaniami oraz oceny do kontynuowania działalności oceniono na około $40 \%$. Poniżej $40 \%$ udziału mają due diligence, audyt jakości, audyty społeczne i ochrona środowiska, przejście na MSR/MSSF, audyt nagród dla zarządu i wdrożenie XBRL. Typy wykonywanych zadań audytowych przedstawiono na rysunku 11. 
Planowanie audytu oparte na ryzyku

Inna komunikacja elektroniczna

Przegląd analityczny

Próbkowanie statystyczne

Elektroniczny projekt dokumentowania

Zbieranie danych

Techniki audytu wspierane komputerowo

Samoocena kontroli

Oprogramowanie tworzące diagram sekwencji działań

Benchamrking

Audyt ciągły

Aplikacje mapujące procesy

Narzędzia oceny jakości opracowane przez IIA

Zbilansowana karta dokonań lub podobne narzędzia

Techniki kompleksowego zarządzania

Oprogramowanie do mapowania procesów
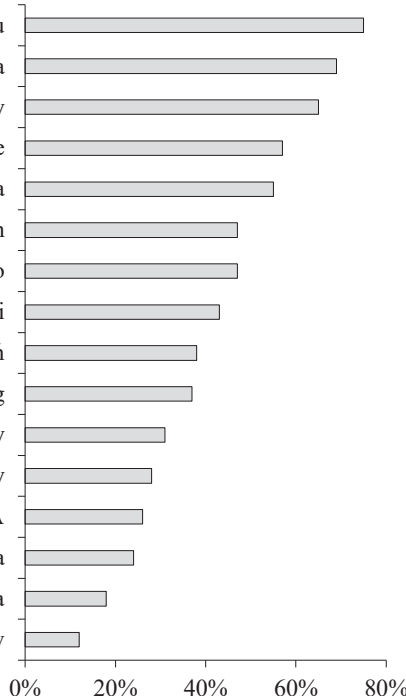

Rysunek 10. Narzędzia i techniki audytu wewnętrznego

Źródło: Bailey (2010), s. 25.

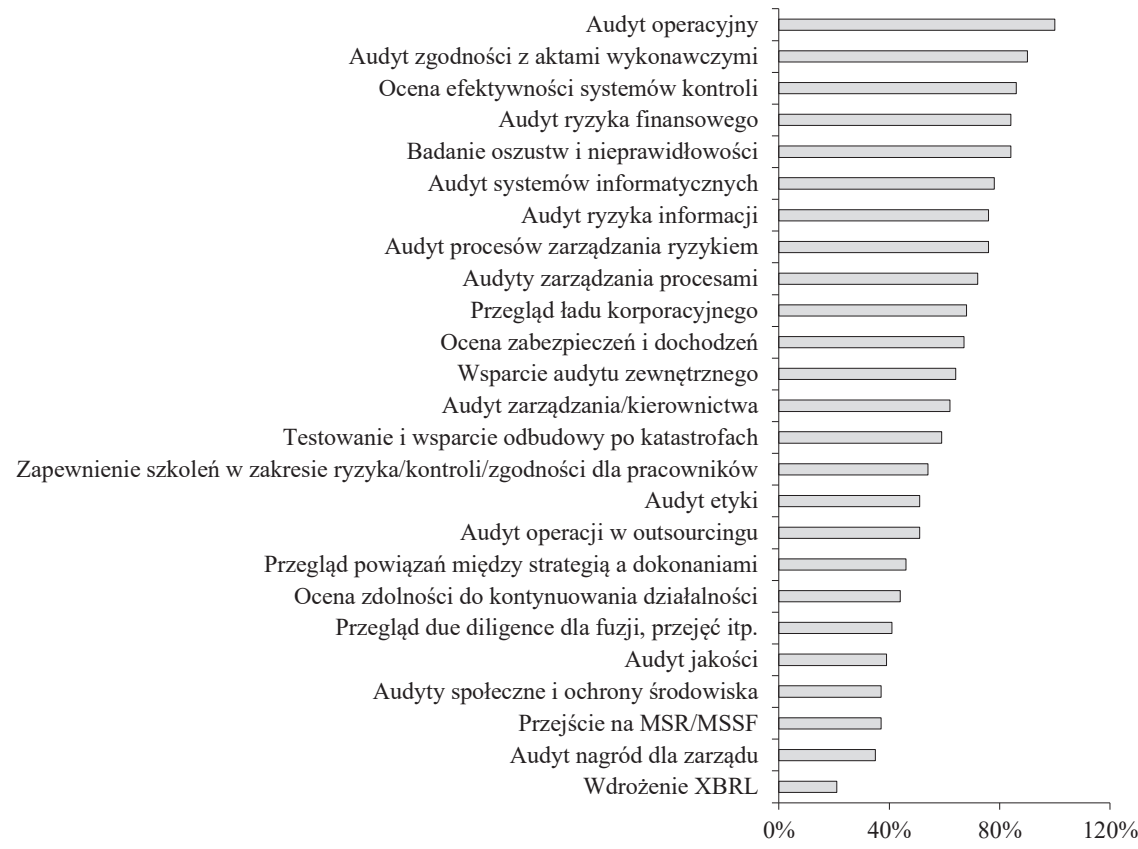

Rysunek 11. Typy wykonywanych zadań audytowych

Źródło: Bailey (2010), s. 35. 


\section{Uwagi końcowe}

Audytorzy wewnętrzni funkcjonują na świecie od wielu lat. W badaniach IIA występowały organizacje, w których audyt wewnętrzny istnieje nawet dłużej niż 50 lat. W przeważającej części wskazywano, że audyt wewnętrzny funkcjonuje w organizacji od 11 do 25 lat.

Wraz z ewolucją audytu wewnętrznego zmieniła się rola audytora wewnętrznego (tab. 2).

\section{Tabela 2}

Zmiany modelu audytora wewnętrznego

\begin{tabular}{|c|c|c|}
\hline Aspekt & Stary model & Nowy model \\
\hline $\begin{array}{l}\text { Przedmiot zainteresowania audytu } \\
\text { wewnętrznego }\end{array}$ & Kontrola wewnętrzna & $\begin{array}{l}\text { Ryzyko związane z podejmowaną } \\
\text { działalnością }\end{array}$ \\
\hline Reakcja audytu wewnętrznego & $\begin{array}{l}\text { Reakcja post factum, o charakterze } \\
\text { nieciągłym, obserwatorzy inicjatyw } \\
\text { planowania strategicznego }\end{array}$ & $\begin{array}{l}\text { Presja w czasie, stałe } \\
\text { monitorowanie, uczestniczenie } \\
\text { w tworzeniu planów strategicznych }\end{array}$ \\
\hline Ocena ryzyka & Identyfikowanie czynników ryzyka & $\begin{array}{l}\text { Planowanie scenariusza reagowania } \\
\text { na zagrożenia }\end{array}$ \\
\hline $\begin{array}{l}\text { Zakres badania audytu } \\
\text { wewnętrznego }\end{array}$ & Znaczenie kontroli & Znaczenie ryzyka \\
\hline $\begin{array}{l}\text { Metody stosowane przez audyt } \\
\text { wewnętrzny }\end{array}$ & $\begin{array}{l}\text { Nacisk położony na kompletność } \\
\text { szczegółów w sprawdzaniu } \\
\text { kontrolnym }\end{array}$ & $\begin{array}{l}\text { Nacisk położony na znaczenie } \\
\text { ryzyka w szerokim zakresie } \\
\text { w podejmowaniu działalności }\end{array}$ \\
\hline Zalecenia audytu wewnętrznego & $\begin{array}{l}\text { Wewnętrzna kontrola: } \\
\text { - wzmocniona, } \\
\text { - przynosi korzyści finansowe, } \\
\text { - skuteczna i faktyczna }\end{array}$ & $\begin{array}{l}\text { Zarządzanie ryzykiem: } \\
\text { - unikanie lub dywersyfikacja } \\
\text { ryzyka, } \\
\text { - podział lub przeniesienie ryzyka, } \\
\text { - } \text { kontrola lub przyjęcie ryzyka }\end{array}$ \\
\hline Raporty audytu wewnętrznego & $\begin{array}{l}\text { Odnoszą się do kontroli } \\
\text { funkcjonalnych }\end{array}$ & $\begin{array}{l}\text { Odnoszą się do procesów } \\
\text { związanych z ryzykiem }\end{array}$ \\
\hline $\begin{array}{l}\text { Rola audytu wewnętrznego } \\
\text { w organizacji }\end{array}$ & Funkcja niezależnej oceny & $\begin{array}{l}\text { Zintegrowane zarządzanie ryzykiem } \\
\text { oraz zarządzanie na poziomie } \\
\text { korporacyjnym }\end{array}$ \\
\hline
\end{tabular}

Źródło: opracowanie własne.

W ciągu wielu lat funkcjonowania audytu wewnętrznego ulegały zmianom oczekiwania wobec audytora wewnętrznego. Można wyróżnić stary i nowy model audytora wewnętrznego. Zmiana modelu starego na nowy nastąpiła w ostatnich latach XX wieku. Audytor wewnętrzny starego typu koncentrował uwagę na kontroli wewnętrznej czynności już dokonanych, z niewielką identyfikacją czynników ryzyka. Audytor wewnętrzny nowoczesnego typu skupia uwagę na ocenie ryzyka, planowaniu scenariuszy, reagowaniu na zagrożenia i reakcji w czasie rzeczywistym, poprzez stałe monitorowanie ryzyka i jego dywersyfikację. 


\section{Literatura}

Alkafaji, Y., Hussain, S., Khallaf, A., Meldalawieh, M.A. (2010). Characteristics of an Internal Audit Activity. Report I, Institute of Internal Auditors, Altamonte Springs, FL.

Bailey, J. (2010). Care Competencies for Today`s Internal Auditory. Report II, Institute of Internal Auditors, Altamonte Springs, FL.

Winiarska, K. (2017). Audyt wewnętrzny. Teoria i zastosowanie. Warszawa: Difin.

\section{QUALIFICATIONS OF INTERNAL AUDITORS AROUND THE WORLD}

Abstract: Purpose - The purpose of the article is to present the research assessing the state of education, competence and skills of internal auditors around the world.

Design/methodology/approach - In order to write the paper, report prepared on request of the Institute of Internal Auditors (IIA) were used.

Findings - The popularisation of the results of the IIA research highlight the role of internal audit in the world.

Originality/value - The question used in the IIA questionnaire research may be used for research purposes in these countries where internal audit is regulated by law.

Keywords: internal auditors, internal auditor qualifications

\section{Cytowanie}

Winiarska, K. (2017). Kwalifikacje audytorów wewnętrznych na świecie. Finanse, Rynki Finansowe, Ubezpieczenia, 3 (87/1), s. 205-215. DOI: 10.18276/frfu.2017.87/1-19. 